\title{
MEDIA LITERACY AMONG ADOLESCENTS : PREVENTIVE TO THE IMPACT OF PORNOGRAPHY ON YOUTUBE SOCIAL MEDIA IN SOUTH TANGERANG
}

\author{
Nur KHOLISOH $^{1 *}$, Siti Muslichatul MAHMUDAH ${ }^{2}$, Mohamad SAIFUDIN $^{3}$ \\ ${ }^{1,2}$ Universitas Mercu Buana, Indonesia \\ ${ }^{3}$ Universiti Sains Malaysia \\ *nur.kholisoh@mercubuana.ac.id
}

\begin{abstract}
The social problem that is rife today is related to the impact of pornography on social media among children and adolescents. Pornography has a very big danger, especially teenagers. Adolescent psychology is still unstable and the growth of sexual hormones in adolescents, making pornography has a danger (negative impact) is very large on adolescents. Not only drugs that contain addictions, pornography also makes viewers addicted / addicted. For teens, addicted to porn sites (cybersex) will make learning rhythm become chaotic. In general, addiction to porn sites will have a negative impact on one's character. Based on research by Bingham and Piotrowski in the Psychological Report entitled On-line Sexual Addiction, the character of people who are addicted to cybersex are: Inadequate social skills, preferring to wrestle with sexual fantasy, engrossed in communication with the characters created by him. own imagination, and unable to control themselves not to access porn sites and forget time. The results of a Child Protection Commission (KPA) survey of 4,500 teenagers revealed, 97 percent of teens had watched or accessed pornography and 93 percent kissed their lips. Like chemical addiction, pornography addicts tend to replace something important with sex or other forms of pornography. People who are addicted to pornography usually use media such as magazines, porn videos or most often is the internet. Adolescents who generally still live with parents, therefore the role of supervision from parents is needed to provide an understanding of the use of social media wisely and directed to use social media positively. Parents can only provide gadgets as an easy access for their children to explore YouTube social media, but basically they also lack understanding about the media so there is still a lack of awareness for parents to control the content that their children see and consume on social media YouTube. Therefore, the need for media literacy training among adolescents is a form of prevention of the impact of pornography on YouTube social media in Kembangan Utara.
\end{abstract}

Keywords : Media Literacy, Pornography, Media Social, Youtube, Prevention.

\section{BACKGROUND}

South Tangerang is a city in the province of Banten, Indonesia. Located $30 \mathrm{~km}(19 \mathrm{mi})$ on the southwestern border of Jakarta, the city forms part of the Greater Jakarta metropolitan area. It was administratively separated from Tangerang Regency on October 29, 2008. South Tangerang City is located in the eastern part of Banten Province, namely at the coordinate point $106^{\circ} 38^{\circ}-106^{\circ}$ 47' East Longitude and $06^{\circ} 13^{\prime} 30^{\prime \prime}$ “- $06^{\circ} 22^{\prime} 30^{\prime \prime}$ Latitude South and administratively consists of 7 districts, 49 subdistricts and 5 villages with an area of $147.19 \mathrm{~km} 2$ or 14,719 hectares.

The municipality of South Tangerang is divided into seven districts (kecamatan), tabulated below with their areas and population totals from the 2010 Census and the official estimates for mid 2019. The centre of South Tangerang is the Ciputat district. The table also includes the number of administrative villages (rural desa and urban kelurahan) in each district, and its postal codes. The districts are sub-divided into 49 urban villages (kelurahan) and five rural villages (desa).

The population is an asset for an area that has a big enough role in determining the acceleration of regional development if it is supported by good quality. The population has two roles in the economic field, namely as producers and consumers. The population development of an area is determined by the rate of birth, death, and population migration. Based on the results of the 2010 Population Census by the BPS of South Tangerang City, the population of South Tangerang City was 1,290,322 people, the population density in this area reached 8,856 people / km2 in 2010. The male population was 652,281 people while the female population was 638,041 people. The sex ratio is 102.23 , which indicates that there are slightly more males than females.

South Tangerang City has a motto "Intelligent, Modern and Religious", noble qualities that challenge and hope for all parties. Hoping to have a bright future absolutely requires a good design including, measured stages, at least referring to the concept of life to be realized: intelligent-modern- religious. The future is bright in the context of "Smart" regarding the world of education with all aspects of its relationship: physical infrastructure (school buildings, laboratories, libraries, and the like), software, design curriculum content, administrative systems and procedures, as well as the welfare of employees and educators, including the quality standards of students.

The bright future in the context of "Modern" involves many factors of life which are interrelated, it cannot be denied that formal education is structured dominantly to shape human behavior. A person or a group of society can be said to be modern, generally when the relevant community group has a "mutually" manners. respect, ethics, and culture ", rarely get caught up in open and prolonged conflicts. The bright future in the context of "Religious" is the pinnacle of perfection in life, it is almost certain that when a group of people or the majority of the people of a region have reached the intelligent and modern phase of life, then actually that society can also be said to have entered the religious phase. 
The critical problem that afflicts teenagers in South Tangerang is the problem associated with the impact of pornography on social media among teenagers. Pornography has a huge danger, especially for teenagers. Adolescent psychology is still unstable and the growth of sexual hormones in adolescents, making pornography has a very large danger (negative impact) on adolescents.

Not only drugs that contain addiction, pornography also makes the connoisseur addicted. For teens, addicted to porn sites (cybersex) will make learning rhythms chaotic. In general, being addicted to porn sites will have a negative impact on one's character. Based on research by Bingham and Piotrowski in Psychological Report entitled On-line Sexual Addiction, the character of a person who is addicted to cybersex is: Social skills are inadequate, preferring to deal with fantasies of a sexual nature, fun communicating with figures created by his own imagination, and not able to control themselves from accessing porn sites and forgetting time. The results of the Child Protection Commission (KPA) survey of 4,500 adolescents revealed that 97 percent of teens had watched or accessed pornography and 93 percent had kissed their lips. Like chemical addiction, pornography addicts tend to replace something important with sex or other forms of pornography. People who are addicted to pornography usually use media such as magazines, pornographic videos or most often the internet.

\section{Research Problem}

During this time many parties who have not bothered to provide healthy information about sex to children and adolescents. Many parents themselves still consider sex as something taboo, so they never give healthy information about sex to their children, especially those who are in their teens. This is also due to their own lack of information about sex and do not know how to communicate good sex to children. Therefore, to fulfill his great curiosity about sex, often teenagers look for alternatives by enjoying pornography in secret, both alone and with their friends.

Even more alarming is when a child is addicted to pornography on the Internet. Within a week there were more than 4000 porn sites created. What a worrying number. Initially, maybe a child does not intend to view pornography and will use the Internet for good purposes. But this porn site can appear suddenly when a child is looking for information material for his schoolwork or for other purposes. A child who is still innocent can not judge the good or bad of a thing, so a child aged 8-12 years is often the target.

Not surprisingly, sexual crimes committed by adolescents and minors are increasingly prevalent lately. Various adverse effects of watching porn films for minors are mental and moral damage which impact on sexual crimes such as rape, pregnancy out of wedlock, venereal disease, and various other

adverse effects. From the habit of watching, then want to try, addicted to even a few of those who try to make their own obscene videos for the sake of perpetuating sexual activity with a partner.

In courtship relationships, relationships that develop become unhealthy. People who are involved in pornography will make their lovers as objects of sexual acts that they watch through porn sites. In addition, in many cases, pornography makes a person lose his power, pornography can damage sexual relations with a partner because they are accustomed to imagining others in sexual relations.

Imagination is one of the strong effects of pornography. The value and sexual purity actually become corrupted. Once a person sees pornography, all images and scenes will be embedded in his subconscious mind. That will bring it deeper. True moral values fade away, giving rise to a confusing double standard. As a result, he is far from spiritual activities. Praying will not be able to concentrate because the mind is filled with images and sexual scenes. Therefore, it is necessary to carry out media literacy among adolescents to prevent the impact of pornography on social media, especially YouTube.

\section{Solution}

Currently, the spread of pornography sites is mostly happening on social media. Social media is an online media, where users can easily participate and share information. Social media technology takes various forms including magazines, internet forums, weblogs, social blogs, microblogging, wikis, podcasts, photos or images, videos, social rankings and bookmarks. Social media has the following characteristics: the message delivered is not only for one person but can be many people for example messages via SMS or the internet, messages are delivered freely, without having to go through a Gatekeeper, messages delivered tend to be faster compared to other media, and the recipient of the message that determines the time of interaction

The users of web sites share media content, such as videos, ebooks, images, and others. YouTube is a popular video sharing website, where users can load, watch and share video clips for free. Generally the videos on YouTube are music clips (video clips), movies, TV, and videos made by the users themselves. The format used by videos on YouTube is .flv which can be played on web browsers that have the Flash Player plugin.

Most content on YouTube is uploaded by individuals, although media companies such as $\mathrm{CBS}, \mathrm{BBC}$, Vevo, Hulu, and other organizations have uploaded their material to this site as part of YouTube's partnership program. Unregistered users can watch videos, while registered users can upload an unlimited number of videos. Normatively applicable law, videos deemed to contain offensive content can only be watched by registered users aged 18 years or over.

However, in reality many children and adolescents under the age of 18 can access pornographic videos on YouTube social media. Pornographic images that are 
on pornographic websites, usually will be attached and difficult to be removed in the minds of children in a long period of time. Technology is one of the media that can help humans to live better, but if the technology is misused, it can destroy its users. The internet is one part of technology that is considered very important in accessing information and means to communicate, but at the same time can become a weapon to eat if it is not used wisely. Based on the survey results, Indonesia ranks seventh largest porn movie downloader in the world. Downloaders of porn sites in Indonesia are dominated by youth, adolescents and even minors. Most porn sites are downloaded via internet cafes, because they are afraid of being found out by parents if they do it at home

Therefore, adolescents can no longer be indifferent and do not care about the current situation and conditions. Adolescents' understanding of pornography is very important in preventing (negative) the occurrence of negative effects of pornography on social media, especially social media YouTube. Adolescents need to be more caring and alert in their educating, especially who are in Kembangan Utara Village.

Attitude is a reaction or process of someone who is still closed to a stimulus or object. Attitudes cannot be seen directly but can only be interpreted in advance from closed behavior. In general, the notion of attitude is the feelings, thoughts, and tendencies of someone who is more or less permanent in knowing certain aspects of their environment. The components of attitude are knowledge. feelings, and inclination to act. In another sense, attitude is an evaluative inclination towards an object or subject that has consequences that is how a person is dealing with the object of attitude. The attitude contained in the individual will give color or style of behavior or actions of the individual concerned. By understanding or knowing an individual's attitude, it can be predicted the response or behavior that will be taken by the individual concerned.

The internet has become an inseparable part of modern life. Prohibit internet adolescents such as prohibiting children from using electricity and returning to the stone age. The answer should not be oriented back to the past or anti-modernization. Then the question that needs to be answered as well, How to protect teens from pornography on social media especially YouTube?

In overcoming this problem, adolescents' understanding of pornography is very important. There are still many adolescents who are not aware of the dangers and negative impacts of social media, especially those related to pornography. The dangers on the Internet and the problem of Internet addiction are not insurmountable. By knowing the negative effects of the Internet, adolescents can protect themselve.

The rise of pornography on social media YouTube is a regular spectacle of young people and teenagers. This phenomenon also appears among adolescents in Kembangan Utara who can easily access social media, including YouTube. To avoid and anticipate the negative effects of pornography on YouTube social media, it is necessary to conduct media literacy activities among teenagers in Kembangan Utara. There are several things that will be conveyed in media literacy activities among teenagers in Kembangan Utara to avoid and anticipate the negative effects of pornography on YouTube social media, including:

1. More sort of spectacle, especially those on YouTube social media because of the more diverse content displayed that can be positive or negative.

2. It is hoped that it is not easy to try the trends that are on YouTube, especially if the trend is not in accordance with the norms in the community.

3. It is hoped that it does not rule out the possibility of using YouTube positively, other than as a means to seek information, as well as a means to create and develop creativities.

\section{Output Target}

Technology is like two sides of a coin, one side contains a positive element, while on the other side it is negative and can be a threat to its users. This can also happen among teenagers who can access various information through social media. Threats to the dangers and negative impacts of social media, especially YouTube, include pornography. This can be prevented by taking preventive measures through media literacy activities.

Media literacy is a person's ability to understand, analyze, and deconstruct media imaging. The ability to do this is so that the audience as media consumers (including children and adolescents) become aware of how the media are constructed (made) and accessed. This activity is intended so that adolescents can have the ability to understand, analyze, and criticize content on YouTube social media to avoid the negative effects of pornography that are found on YouTube social media.

After participating in media literacy activities, it is targeted adolescents can know and understand the dangers and negative effects of pornography on social media, especially YouTube. In addition, this activity is expected to empower teenagers to be able to understand, analyze, and critique content that is on YouTube social media to avoid the negative effects of pornography that is widely found on YouTube social media. The output of this media literacy activity is the improvement of values in society.

The target of this activity is adolescents who use digital media namely YouTube and social media. Adolescents' understanding of pornography is very important in preventing (negative) the occurrence of negative effects of pornography on social media, especially social media YouTube. Adolescents need to be more caring and alert in their educating, especially who are in Kembangan Utara.

After completing this media literacy activity, adolescents are expected to have the ability to consider, 
analyze, and criticize content on YouTube social media to avoid the negative effects of pornography found on YouTube social media. In addition, by using media literacy, make them as individuals who are "media literate". Connected, individuals who are knowledgeable, knowledgeable, able to analyze, assess, and be able to debate the information or media messages obtained, so they can get a position on a particular issue or issue, and are easily carried away and negative things.

\section{METHODS}

This activity is a media literacy activity that includes seven skills, namely: Analysis (related to the ability to understand the content and content and dismantle and review a message or information from a media), evaluation (able to provide an assessment of an information message that the media convey), Grouping ( able to classify the various information that we obtain from a media in a certain similarity and difference), Induction (ability to analyze and review information from a specific nature in a small scope towards a general character as a whole), Deduction (ability to analyze and review information general nature then describes it into specific information), Synthesis (the ability to re- arrange a message or information from a media into a message in a new structure that is different from before), and Abstract (complete abilities and skills, starting from analyzing, describing right, look for problem points or issues to summarize the message and present it again in a language that is easier to understand).

This training uses several methods or methods, namely: discussion, presentation and lecture. Focus group discussions (FGDs) are conducted by dividing participants into several small groups to discuss the themes or issues raised by the speakers, especially those related to pornography's negative impacts on social media, especially YouTube media. After the discussion is over, representatives of each group present the results of their group discussions alternately which are then responded to or responded to by other discussion groups.

Furthermore, the results of focus group discussions (FGD) were discussed by the speakers by providing direction and explanation through lecture techniques. In this discussion, the speakers conveyed the main material about pornography and the egalistic impact of pornography on social media, especially YouTube media. Furthermore, it also discusses the Empowerment of Parents' Attitudes to prevent (preventive) the impact of negative pornography on social media Youtube. To further clarify and provide a good understanding of the material presented, the speakers gave examples relating to pornography on social media.

\section{RESULTS AND DISCUSSION}

The community service program entitled Media Literacy among Adolescents: Preventive to the Impact of Pornography on YouTube Social Media in South Tangerang was held online on Monday, March 8, 2021 through digital media zoom meetings due to the pandemic still hitting this year. This program is in collaboration with one of the international schools in the South Tangerang City area, Global Islamic School. The activity in the form of a webinar was attended by teachers and students from the Global Islamic School. Speakers in the webinar also consisted of Mercu Buana University and also Universiti Sains Malaysia. The event was hosted by students from Mercu Buana University who greeted and livened up the atmosphere in the webinar with their approach to the audience, namely students at the Global Islamic School, although online using digital media, they were still enthusiastic about this community service activity.

Participants are coordinated to get a Zoom Meeting link for access to and take part in this community service program webinar. The series of events began with the opening remarks delivered by Mrs. Dwi Kurniawati, S.Pd as the Deputy Curriculum of the Global Islamic School. After that, the direct material presentation was given to the participants in parallel, first from the Mercu Buana University first and then followed by a material presentation session from Universiti Sains Malaysia. The material presented was made with not too much text but made it more telling stories such as sharing information so that it could be easily accepted and understood by the teenage participants, especially when it was carried out online, the presentation of the material had to be made as interesting as possible in order to avoid the participants feeling bored.

The material presented is education in terms of media literacy, especially for Global Islamic School students who are still teenagers or as the younger generation to be able to understand the importance of preventing the impacts of pronography that are often found on social media. As is well known, teenagers are very close to today's technology, especially the freedom to use smartphones which not only function as a medium of communication but also as a medium for seeking information, whether it is about school knowledge or information as limited as entertainment for its users. One of them is the use of social media for teenagers who are inseparable from their daily life, almost all teenagers have social media accounts and actively use them, this should be a common concern because there is still a lack of protection and supervision from the media regarding the content that published so that these teenagers may find access to viewing pornographic content from social media, if this is allowed to continue, it will have an impact on adolescents who continue to consume pornographic content both internally for themselves and on their environment. The most popular social media for searching and viewing audio-visual content is Youtube, where users can easily search for information by typing in keywords in the search field, then a lot of content that is relevant to the keywords you are looking for will appear. From this ease of access and the lack of filters for Youtube users to get age-appropriate content, this can be an opportunity for teenagers who deliberately want to find 
pornographic content to see. Therefore, it is important to have a good understanding and form of self-respect for social media users, especially teenagers, to know the limitations of content on social media.

Adolescence is a stage where someone is trying various things to explore themselves, their curiosity about many things also affects their search for a variety of information, supported by current conditions as well as the sophistication of technology that exists especially in digital media. Therefore, it is important for every teenager to be equipped with understanding and knowledge of digital media literacy so that they can also take advantage of the use of social media positively to have a positive impact on themselves, lest teenagers misuse the use of social media for negative things because it is also will have a bad impact, including pornographic content that is consumed continuously. Some of the discussions in the material for this community service program include the provision of information on applicable regulations related to information technology and pornography, after which there is an understanding of matters including pornography, porno-action, types and forms to the impact that pornography can cause.

In this community service activity material, knowledge of how to solve the problem of pornography is also given to be carried out from a security system for social media platforms and also settings on digital media that are often used, including ways to overcome those who are addicted to pornography by various efforts were made consistently to keep it apart from this. This material is not only conveyed from one perspective with the situation in Indonesia, but also gets additional material from the point of view of the situation in Malaysia regarding the impact of pornography on social media. During the presentation of the material, it was seen that the results of the webinar of this community service program were that the participants who were teenagers actually already knew and understood the presence of social media for themselves, including about its benefits and other impacts that could be generated, both negative and positive, which returned to its users in take advantage of social media. Regarding ponographies that are often found in social media, they also feel that it is often found in various types and forms which in fact some are unconsciously included in the category of ponographical content. Therefore, when the material presentation has been completed, students are given the opportunity to ask questions if there are things that are not understood about the material or about the impact of pornography on social media. The students were quite active in asking questions to the informants, especially there were some foreign terms that they wanted to confirm about pornographic content, including the psychological state of people who were addicted to pornographic content, they wanted to know the form of impropriety someone had regarding pronography addiction, and a wider impact in the future if the addiction is not treated immediately.
The hope of implementing community service programs in this media literacy educational webinar is that teenagers can control themselves in the use of social media and be wiser in using social media according to their needs and understand the limitations they must know according to their current age. Also related to the large number of pornographic content on social media, especially YouTube, teenagers must be equipped with good knowledge and understanding to filter the content they will consume, take precautions for themselves so they don't become addicts to pornographic content. With the education provided, it is hoped that teenagers can choose the information they receive from social media so that they are not adversely affected by the information received, one of which is pornographic content.

\section{CONCLUSION AND SUGGESTIONS}

This community service program at Mercu Buana University with the theme "Media Literacy among Adolescents: Preventive to the Impact of Pornography on YouTube Social Media in South Tangerang" has been well implemented. The conclusion of the activities carried out in this community service program is that basically adolescence is a stage where a person is trying various things for his own exploration, their curiosity about many things also affects in finding a variety of information, especially the current situation is supported by sophisticated technology. exists primarily in digital media. The results of the webinar on this community service program also show that the participants who are teenagers actually already know and understand the presence of social media for themselves, including about its benefits and other impacts that can be generated, both negative and positive, which return to users in utilizing the presence of media. social. Regarding ponographies that are often found in social media, they also feel that it is often found in various types and forms which in fact some are unconsciously included in the category of ponographical content. Therefore, it is important for every teenager to be equipped with understanding and knowledge of digital media literacy so that they can also take advantage of the use of social media positively to have a positive impact on themselves, lest teenagers misuse the use of social media for negative things because it is also will have a bad impact, including pornographic content that is consumed continuously.

Based on the results of Community Service activities carried out in collaboration with the Global Islamic School located in the Serpong area of South Tangerang City, the suggestion that can be conveyed is that this activity can continue to be carried out in the future so that it can provide sustainable education for teenagers who become the next generation of the nation, in this case, is related to understanding and knowledge in the field of digital media literacy. 


\section{REFERENCES}

Arifin Anwar, (1998) Ilmu Komunikasi : sebuah Pengantar Ringkas, Rajawali Press, Jakarta

Devito, Joseph A, (1997) Komunikasi Antar Manusia Kuliah Dasar, e.d. Ke-5, $\quad$ P r o f e s s i o n a 1 Books, Jakarta

Fahrudin, Adi, (1994). Pemberdayaan, Partisipasi dan Penguatan Kapasitas Masyarakat. Bandung: Humaniora.

Lord, John dan Peggy Hutchison, (1993) E Process of Empowerment: Implications for theory and Practice, Canadian Journal of Community Mental Health, 12: 1.

Mc. Quail, Dennis Sven Windhal, (1996) Communication Models, Longman Inc, USA Mulyana Deddy, (2000) Ilmu Komunikasi suatu Pengantar, PT Remaja Rosdakarya, Bandung
Paul, R. Wayne, J Don F, (2000) Komunikasi Organisasi (Editor : Deddy Mulyana, M.A., Ph. D) PT Remaja Rosdakarya, Bandung.

Sandjaja, Sasa Djuarsa, (1993) Pengantar Komunikasi, Univeristas Terbuka, Jakarta.

Sulistiyani, A. Teguh dan kawan-kawan, (2017) Proses Pemberdayaan Masyarakat Desa Sitimulyo, Kecamatan Piyungan, Kabupaten Bantul dalam Pembentukan Kelompok Pengelola Sampah Mandiri, Indonesian Journal of Community Engagement, Vol. 02, No. 02.

Wilonoyudho, Saratri, Model Pemberdayaan Masyarakat dalam Pengendalian Banjir yang

Berwawasan Lingkungan di Semarang, Jurnal Manusia dan Lingkungan, Vo. 16. No. 2,Juli 2009 